日本組織学記録, 巻 18, 号 1 (昭和 34 年 9 月). 頁 $79-105$.

Arch. hist. jap. Vol. 18, n. 1 (September 1959). P. 79-105.

東京慈惠会医科大学組織学教室 (主任: 吉村不二夫教授).

Dept. of Histol. and Embryol, Tokyo Jikeikai School of Med., Minato-ku, Tokyo

(Director: Prof. F. YOSHIMURA).

\title{
哺乳動物副腎皮質球状層と束狀層との移行部の比較觀察.
}

\section{Comparative Observations for the Transitionary Locations of Zona glomerulosa to Zona fasciculata in Various Mammalian Adrenal Cortices.}

\section{伊 東鉄男 Tetsuo ITO.}

(Received June 5, 1959.)

Deane, Shaw 及び Greep (1948) によって提唱された副腎皮質 2 元論は球状層と 束状層以下とが形態学上ばかりでなく, 分泌されるホルモンの種類においても全 く暴なるものであり，前者からは鉣質コルチコイドが，後者からは糖質コルチコ イドが分泌されると説くものであり，それは，现在では，多くの賛成者と支持者 とを得ている機能局在論の先鞭をつけたものであった. Selye と Stone (1950) は この説を補足強化したので，その信頼性は一篔えまった． 2 元論の中心思想は移 行層の存在に基礎づけられている，既に知られている如くラットでは両層の間に 移行層が存在し，てのものが脂肪顆粘を久いているとてろから sudanophobic zone ともいわれている，Deane 等が実験に用いた動物は凡てラットであり，移行層が 球状層と束状層との細胞配列上の連続性を遮断すること，下垂华摘出によって本 層が頗る厚くなること等が 2 元論を琗圆にした形態学的基礎となったわけであ る. 2 元論が移行㬝の実在性の上に成り立っている以上, 移行愿の本質を知らず して機能局在論を云々することは危険なことであろう.

さて最近 Cater と Lever (1954) は多くの哺乳動物に於ける移行尿の比較組織 学的研究を行った。 それによるとラット, ネコ, イヌ, ヒッジ, ウサギ, ウマ等で は典型的な移行層は殆ど実在しない，ラット，イヌ，ウマに辛うじて認め得る貧 弱な移行層には脂肪顆粒が存在しないが，他の動物の移行整には若干の脂肪顆粒 が認められるのである. 又生後移行層の発達にはかなりの段階があるほか，性差， 系統上の差もある. Yoshimura (1954) あラット移行層が sudanophobic zone と云 う名には不適当で，常に若干の微細な脂肪顆粮をむつものなるととを，osmium 酸を含む圆定液を用いた標本で証明し，寧ろ移行蟹の細胞は孤立性で小形の扁平 なる細胞が， 2-3 列立んで抢り，胞体内には豊富な弱染性顆粒（Heidenhain 氏 鉄へマトキシリン染色）が存在するために，少数の脂肪顆䊇の存在が復われてわ かり難くなっていると述べた。 そしてての細胞学的特徵で移行層を定義すべきだ と論じた. Cater とLever あ血管配列が球状層と束状層とでは異なるために生じ 
たもので，移行層はその移行部にあると云うだけで別に特殊な層とは云えないと 考えている. 又 Elias と Pauly（1956），Pauly（1957）はヒト，ラットの副腎皮 質の完全な連続切片標本によって再生模型を作製し, 球状層と束状層との移行状 況を丹念に追及した. 間質, 血管, 実質細胞の 3 つの観点から検索を進め, その結 果実質細胞は被膜の直下より䯣質に至るまで真直ぐに伸びており，その間に細胞 索の率続性は全く認められないと述べた。球状曆が独立した細胞集団に見える のは，実は切片に於ける1つの断面を見ているに過ぎないからである．又墨汁注 入ラットで血管走行を見ると, subcapsular plex より下降する血管は, 球状層を大 きな類洞腔となって貫通し, 移行層ではや」㹨少となるが, 束状層に大ると真直 ぐに伸びて網状層に達し，乙〉で再び太くなり，やがて髄質の静脉に移行すると 云い，腺細胞はこの血管走行に一致した配列を示すと結論している．何れにして あ皮質全層に瓦り細胞配列は連続性で一続きであるてとが確認されたわけであ る.

以上の如く無処置ラットにおいてさえ球状層と束状層とが一続きであるが, 動 物がストレスに曝された場合には明らかな連続性を示す像が現われて来る。 Yoshimura (1954) によればラットの一側の副腎を摘出したり，ACTH を投与し たり, 各種ストレスに曝露したりすると, 束状層は同じ太さの細胞索をむって被 膜まで伸びて来る。例え萎縮した球状層が被膜下に埌迫されていることがあって あ, 移行層は例外なく消失することは明らかである，乙うなって来ると皮質全 層はもはや完全なる一続きの闹質性配列を示し, どこが球状層か束状層かの区 別がつき難くなる．而も糖質コルチコイドあ鉱質コルチコイドあ放出が余り阻碍 されることがないので，乙の点では 2 元論には全面的に賛成出来なくなって来る. 少なくとあ移行層は純料に独立した層ではなさそうであると推定されるのであ る.

私は以上の様な観点から, 球状曆と束状癔との続き具合を各種哺乳動物につき 細胞学的に榆討した。 此較組織学的立場より移行曆の実態をつかむととがこの研 究の目的であった。

\section{I. 材 料と方 法.}

健康と思われる雄性成熟のラット（７例），マウス（７例)，ウサギ（ 5 例），モル モット（５例），八ムスター（ 5 例）を一定期間教室の飼育室で管理した。その際 食餌（ふすま 6 , 乙如 6 , 細麦 2 , 魚粉 1 ） と温度には特に注意し, その他ス卜 レスになるような外部環境に動物を置かないようにした。即ち各動物の飼育環境 は原則として一定になる様に努めた。イヌ（３例），ネコ（３例）は雄未熟仔を飼 馴し, 成熟せしめたる後使用した。 ウシ（３例）, ウマ（3 例）, ブタ（３例）等は 屠場で得たあのであるが，商業上去劫してあるものを用いる機会が多かったこと は止むを得ないが，詳細なる条件は不明であった。何れも外見的には健康と思わ 
れる成熟動物であった。 ヤギ（３例）は非去勢雄であった。

実験室用小動物は何れあ断頭致死せしぬたが，イヌ，ネコ，ヤギは ether 麻醉 をしたま〉で副珡を摘出し，その他の動物は屠場で撲殺してから30分以内に材料 をとり出して固定液に投じた。固定液は専らLevi 氏液とZenker-formalin とを用 いた．全て paraffin 包埋を経て，3凡の連続切片とした。切片は脱 paraffin 後, Rubaschkin 氏法で漂白し，Heidenhain 氐鉄へマトキシリン染色を行った。

\section{II. 所見}

a) ラット.

ラットの副腎は薄い結合織性被膜で包まれているが，こ」には通常線維細胞， 結合組織線維，豊富な血管が晃出される （図1）。被膜直下には球状檿がある。ラッ トでは球状層の所謂糸球 (glomerulum)の 発達は良好で，共通の被渵で网まれた多数 の細胞を含む，細胞の境界はわかりにくい （図 4). 各糸球断面は他の動物に此して比 較的大きいのである。然し私の見た多くの 標爻では屡々束状層より被䐃に向い真直ぐ に仲びている一続きの細胞索があり，それ がそのま子被膜に達し（図3），更に被膜下 で弧を画いて反転して再び束状曆に厣る配 列即ち所謂 arcuata の形態を示しているむ のも見られた(図 4 の左)。その場合束状層 に於いて略々規則正しく配列していた細胞 索は被膜近くで配列が大いに乱れ，その部 で核が増加し，束状曆にみられる如き 1 2 列の配列ではなくなり syncytium を形成 する観を呈するのである。 さて典型的な球 状層に於ては被䐉直下の糸状は制合小さ

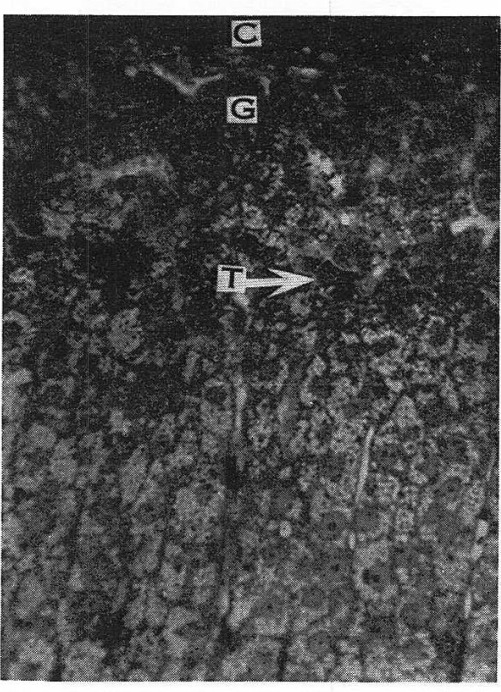

Fig. 1. Adrenal cortex of male rat. The transitional zone $(T)$ which consists of a few layers of flattened cells containing scanty of fat granules exists between Zona glomerulosa $(\boldsymbol{G})$ and fasciculata $\left(F^{\top}\right)$. $C$ capsule. LEVI, iron-hemat. $\times 520$ く，比䡠的末分化の状態に止まり，乙れを構成する細胞屯少なく 1 - 2 ケの核し か認められない，斯くの如く幼若な糸球では未だ脂肪顆䊀が少なく， mitochodria と鉄へマトキシリンに可染される微細顆粒とが可成り存在する。ところがそれよ り内方の糸球はむっと大きく分化を遂げており, 細胞内には粗大な脂肪顆粓が允 満し，その間には少数の微細な可染性顆粒と mitochondria が存在するのである (図 4). 球状層の梁層では粗大脂肪顆粒が特に密集し，その代りに mitochondria や可染性微細顆粒は少なく, 又若干の比較的粗大な可染性顆粘が含まれている. 可染性顆粒は蛋白性顆粘を主成分とするものであろう，或る可染性顆粘の内には 
osmium 酸に還元される不定形微小なる脂肪顆粒が沈着しているととがある，乙 れは Sudan III 等の染色標本 (教室所蔵) では確認出来ない程微細であるが, osmium 酸を使用することによってはじめて証明されるものである。斯かる脂肪 粘子の沈着は可染性顆粒から脂肪顆粓が形成されることを亦しているのではない かと考えられる。このことは既に Yoshimura（1954）によって指摘されたととろ であり, steroid を含む脂肪顆粒以外に，所謂 masked fat の形で蛋白性顆䊉の闷に 絬合しているもの即ち lipoprotein 成分含む可染性顆粒にホルモンの担休とし ての叮能性が暗㐫される.

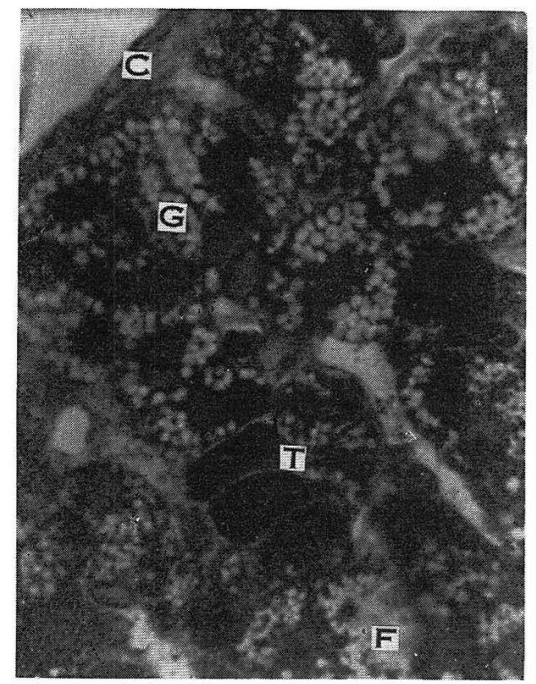

Fig. 2 IIigh magnification of transitional zone of male rat. $C$ capsule, $G$ Zona glomerulosa packed with fat droplets between which minute granules and mitochondria are interspersed, $T$ transitional zone whose dark cell elements are reduced in size, $F$ Zona fasciculata. LEVI, ironhemat. $\times 1200$

さて，ラットは移行層が存在する特別 の動物である(図 1,2). 雄では雌よりこ のものが比较的高頻度に見出される。移 行磨の存在は寧乃 Sudan III 染出標本を 弱搪大で見るのがわかり易い，と云うの は Levi E液沽定では移行層の凡ての微 細な脂肪顆精まで証明されるので, 反っ て移行層全体の存在はわかり難くなって しまうからである。Levi 氏液固定の場合 でもやはり弱拡人で観察した方が強拡大 よりあわかり易い(図 1 と 2 を比較せよ). しかし詳細に钼察すると移行層は案外海 い屯ので 23 列の扁平なる細胞から成 り立っていることが扔る。 それも完全 な層を班成するむのではなく，所々に欠 損部をもち，そこでは束状畨が球状曆に 徐々に移行しており，その間に何等特別 な境界部は認められない、私の観察でも 移行首の細胞は独特の形態及び内部構造 を俏えている，即ち核は横に長軸をむつ 長符四形で，原形質の境界は明瞭でないが，大体に於いて核の形に一致し矢張り

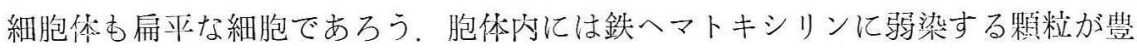
富に存在するが, mitochondria や強染性顆粘は少ない（図 2). 又稀れには少宣の 脂肪顆粒を屯封入している.斯くの如く移行層を唯 sudanophobic zone と云う意味 に解釈することは正しくなく，細胞自身の特微によって定義づけた方が正しいと 思う。一般に移行層は同じ雄ラットでも個体差がはげしいことや，性差がある所 をみても，動物をストレスに曝されない様な条件で飼青することや，性周期に注 意することが大切である。ストレス刺激の場合には移行層は消失することが知ら れている (Yoshimura 1954). しかし全くストレスに曝されていない場合でも，上 
に述べた如く，束状 愿と球状層とが連続 している場所は確か に存在しそこには 2 層の細胞掌の漸進 的变転が認められる のである，従って移 行曆に関する場所的 箬異は個体の队部環 境に基因することが 考えられる.

次に, 移行層の梁 曆に位する束状層で あるがこっでは細 胞は略々 1 列に縦走 し, 長い細胞索を形 成している。細胞率 の間には毛細血管が

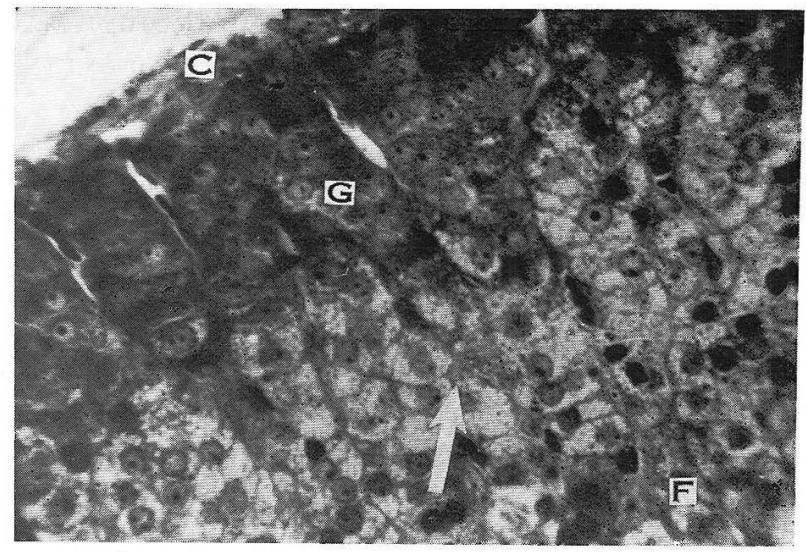

Fig. 3 Adrenal cortex of male rat. The glomerulum formation in Zona glomerulosa $(G)$ is imperfect in a fashion that cell cords perpendicularly invade the uppermost areas of the cortex. The tip is generally shadowed with minute granules and mitochondria, instead of fat granules; however it may be responsible for the accumulaion of fat granules within its cell bodies that the underlying area is pale (arrow). Zona fasciculata $\left(F^{\prime}\right)$ consists of slender cell cords full of fat granules. Between two zones is no longer recognized the intermediary or transitional zone. $C$ capsule. LEVI, iron-hemat. $\times 400$

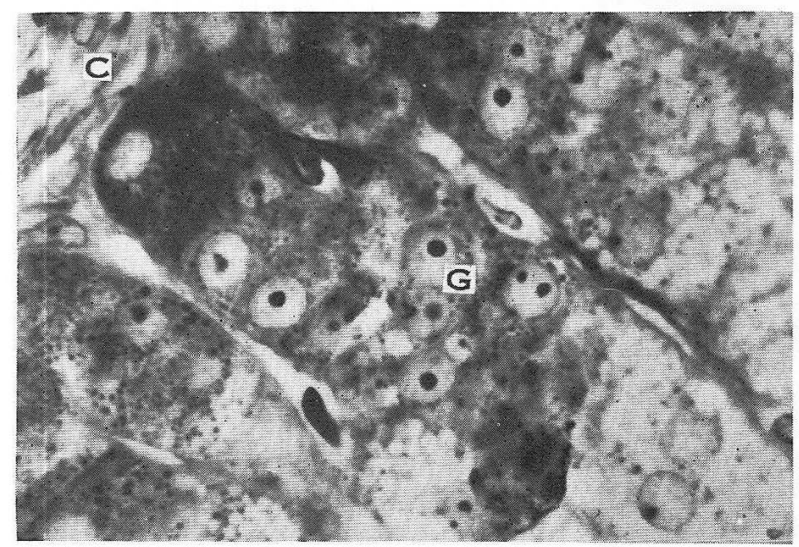

Fig. 4 High magnification of Zona glomerulosa of male rat. The cell cords exhibit an arcuata pattern whose constituents are charged with delicate stainable granules, exclusive of fat granules. The inner adhering part contains, howover, abundant fat granules. $C$ capsule, $G$ Zona glomerulosa. LEVI, iron-hemat. $\times 900$

縦に走っている. 束 状層上層部の細胞は 極めて粗大な脂肪顆 粒が密集して胞集を 渾しているので zona spongiosa टも云わ れている(図1)。一 般に皮質の中で脂肪 顆粒に最む富む所は 束状層表層であって， これに次いで球状層 の深黁である。この 2つの場所に於ける 皮質細胞の内部構造 は似ており，共に鉄 ヘマトキシリンに染 まる少数の可染性顆粒が細胞を満す脂肪顆粒の間に散在するほか, mitochondria 屯若干みられる程度である。上の如く形の一定した小さい脂肪顆粒がぎっしりつ まっている細胞は恐らくホルモンの合成能が活潑である細胞であろうと想像され 
る. 一方 steroid hormone を含むと考えられる脂肪顆精の放出過程は必ずしむ明 らかではなく，放出像は確認されない，網状層に於て認められる不正形の巨大な 脂肪はそのま〉では細胞膜を通過しにくい状態であり, 新生されたばかりの此較 的小形の幼若な脂肪顆粒こそ低分子の脂肪粒子に分解されるならば容易に哭を通 過出来るあのではないかと考えられる. 然し果して lipaseにより低分子の脂肪粒 子にまで分解されなければ膜を通過しないのか, 或は蛋白と結合している masked fat が corticosteroid $\left(\mathrm{C}_{21}\right)$ や 17-ketosteroid $\left(\mathrm{C}_{19}\right)$ の担体であり, proteolytic enzyme によって蛋白結合がとかれるならばすぐに血中に入るものであるか，或は 原形質の基質の中に存在する masked fat がホルモンの担体として一義的な意味 をむっているすのであるか，この点に就ては結諭が得られていない.

b) マウス.

マウスの副腎の表面にはやはり薄い結合織性被裳がみられるが, 球状層の糸球 はラットよりはるかに小さい屯ので, 出現頻度も低い。ややり其通の被脱で被わ

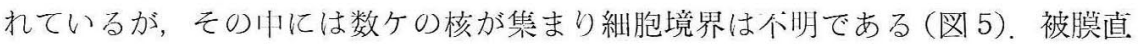
下にはラットと同様幻若な系球, 即ち $2-3$ の細胞よりなる小糸球が例外的に見

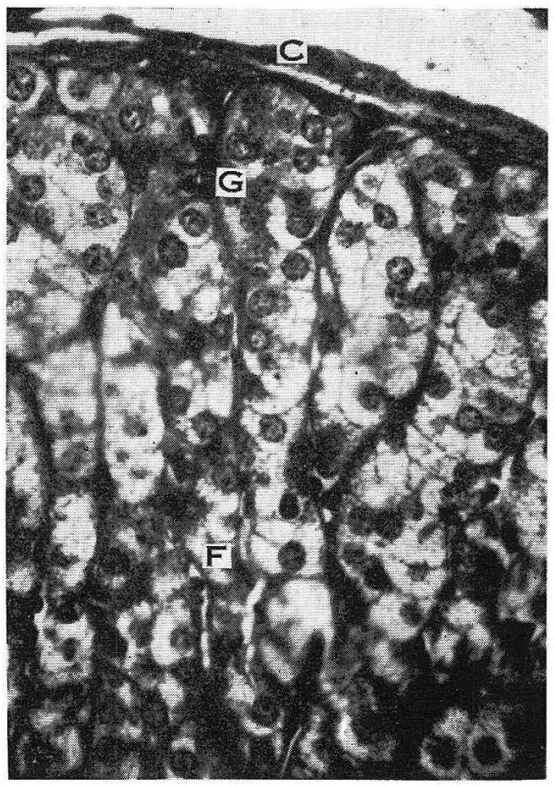

Fig. 5 Adrenal cortex of male mouse. The cell cords protrude eccentrically and reflect on the capsule, eliciting the fasciculo-arcuata pattern. The cells are everywhere enriched with fat granules with an exceptional places connected to the capsule. The cords make the thorough continuation from medulla to capsule. $C$ Zona glomerulosa, $F$ Zona fasciculata. LEVI, iron-hemat. $\asymp 400$
られるが，ラットに於ける様な典型们 なものは少ない，球状觰細胞には多数 の脂肋颗粒が充㶓するが，その最はや はりラットより劣る様である。ラット 乞同様マウスでも球状曆細胞には mitochondria 上可染性顆粒が一般に少な いが，被膜直下の幼若な細胞では脂肪 顆粒が少ない代りに可染性顆精が多く 暗調を带びている（四 6)。

さて、マウスの移行愿であるが、私 の観察ではラットに兌られた様な何等 かの意味の sudanophobic zone は認め られない，只ラットで定義した如き扁 平なる細胞餜（弱染性顆精在豊富に含 む）屯始ど忍められない。次に色々な 断面で球状層の細胞配列状海を観察す ると, 或る場所では束状曆の細胞甞が 更に球状䅣まで伸びて一続きのととが 確められた（図 5)。完全な連続切片に よって検べたわけではないので，凡て の場合に些てはまるとは云えないにし ても, 斯る細胞索を呈する球状曆が確 
認されたわけで，凡ての場合に球状懕は独立した細胞集団を呈することだけは少 なくとも否定し得る。1つの断面によってこの様な連続性が見られることむ, 雨 層の移行の真䒠性を物語るように思える。 また或る標本では束状層が真直ぐに， 細胞の密集した太い細胞甞として上方に伸びて被膜に達し，こ」で反転してドー ムを形造りながら再び束状層に下降し て元に移行しているものが認められた のである(図 6)。己は zona fasciculoarcuata と云わ扎る構造に一致する.

次にマウスの束状層は 1 列又は 2 列 の規則正しい細胞索より成り，その内 部構造はラットと同様である。即ち浅 層では均等性脂肪顆粒が細胞を满たす 特徴があり, 可染性顆精は少ないが, 深層に至るにつれて脂肪顆䊀は少なく なり，反対に可染性顆粒が多数とな る。從って束状層深部では細胞は一般 に暗調を呈する様になるが, 事尖原形 質が浱絔した如き細胞即ち暗調細胞も 散胃される。こっでは顆粒成分はえし い，網状層に近づくにつれて巨大な不 正形の脂肪小滴が見われて来る.

\section{c) ウサギ.}

ウサギの皮質にも明瞭な zonation が あると一般に考劣られている（Roaf 1935)。特に病理学領域ではウサギをス トレス実験に用いて, 形態学的変化を 追栄している研究が多いのであるが，

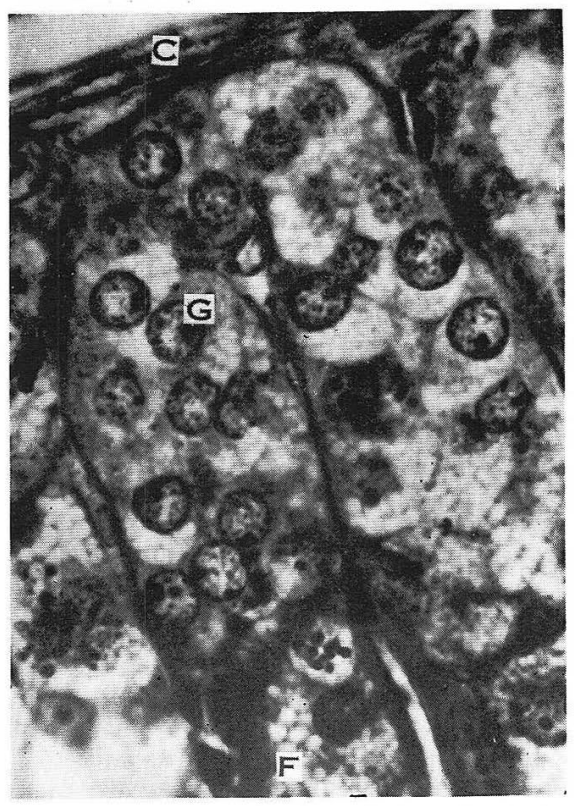

Fig. 6 High magnification of Zona fasciculoarcuata in male mouse. The cells contain a number of fat granules, associated with delicate granules and mitochondria. A sign showing the gradual transformation of glomerulosa cell into fasciculata nature may account for the negation of a transitional zone. $C$ capsule, $G$ Zona glomerulosa, F Zona fasciculata. LEVI, iron-hemat. $\times 900$ ウサギの副腎疋質は上記ラット，マウスとは全百的に異なり，特に球状層の構成 をラットと同列に論ずるととは出来ない，私の锥察では，球状層と束状層とは完 全に一続きであり，もはや球状曆の名に価しない細胞索であり多ど凡て被㴔に達 している(図7)，徒って何処からが球状層であるか殆んど識別できない．今，か りに球状層と思わ扎る様な部分で，而屯此軹的表面の場所を選んで詳細に観察す ると，こ」には2列の横に伸びる核の密集帯がある。1つは被膜の直下で浅い場 所であり，1つはもっと深層であり，何れも大保に於て核の密集部が横に長く続 いている（図 8)，前者の構造をよく見ると，基底萝に当る薄膜が細胞索の上方乃 至側方を被っているが，乙の膜に接近して核の密集部が膜に沿って弧を画くよう に配列している。この核の密集部では個々の細胞の境界は不明である。胞伶には 


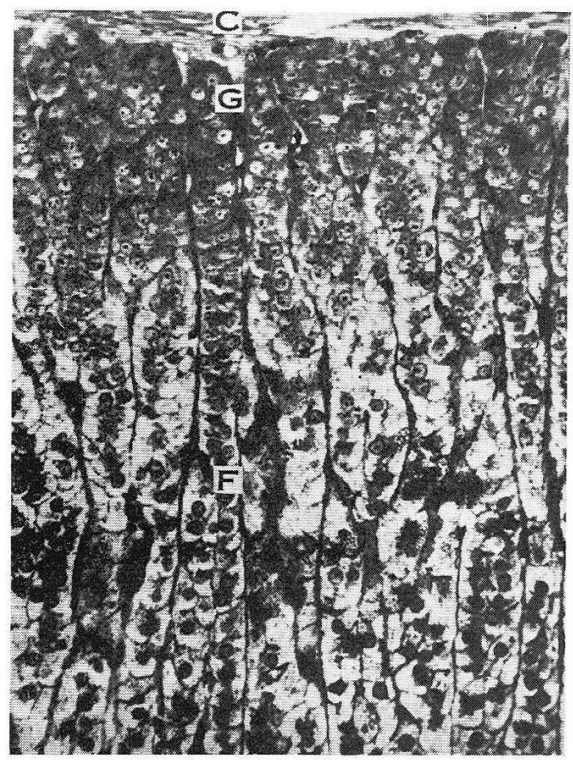

Fig. 7 Adrenal cortex of male rabbit. The straight cell cords arrange compactly throughout the cortex. The supper area is shadowed with the contained fat granules in contrast with the transparent inner part. Zona glomerulosa $(G)$, in real term, is no longer seen since it is only a mass of upward projections of cell cords of Zona fasciculata $\left(F^{\prime}\right)$. C capsule. LEVI, iron-hemat. $\times 200$

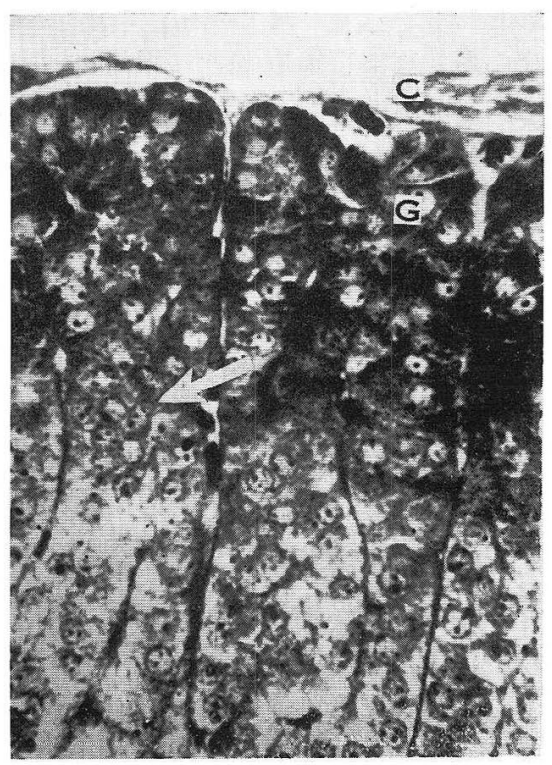

Fig. 8 Zona glomerulosa of male rabbit. Two dark layers are distributed in the outer part of cortex, i. e. the one is the immature cell layer underlying the capsule $(C)$, whose supranuclear regions are packed with tiny stainable granules and the other is dark cell layer representing a mass of nuclei (arrow). G Zona glomerulosa. LEVI, iron-hemat. $\times 400$

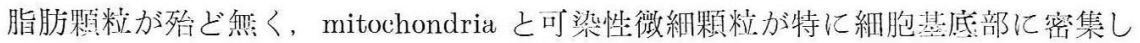
ているのが見られた（図 8)，それより少し深層では可染性粫粒の出现が散在性と なるが，それでもラットに見られた様な粗大な脂肪顆粒は全く存在しない，表面 を造ざかるにつれて脂肪敤粘は若干出現し深部に向うに徒って增加し，個々の細 胞を淽たすに至り，その問に少数の mitochondria と可染怪顆粒が部明されるにす ぎない，一方球状層の最む深尿に当る後者の場合には再び核の密集部が昌られる (図 8).乙」では mitosis の像を証明することは出来なかったが，細胞の境界は全 く不明であり，いわば syncytium の钼を呈している，原形質にはやはり上䢞の如 き可染性顆粒が充満しているが，核の周辺部には原形質基質が残り，こ〉に若干 の mitochondria が存在する。弱拡大でみると上の核の密集部はこの為脂肪顆粒の 充満する束状層よりは暗調を呈し，1つの幅広い带状暗調部を形成している。

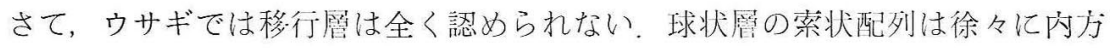

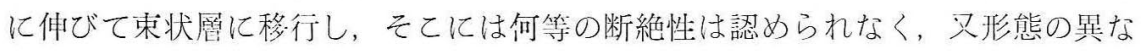

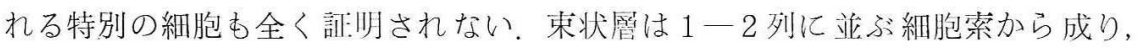
真直ぐに更に内方に伸びている，ウサギの束状層ではラットで見られた表層部の 


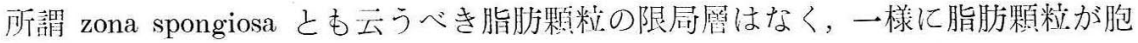
体を満たして深磻に及んでいる，但し脂肪顆粒の大きさは表層の方がや小小さく， 深層では幾分大型になる傾向がみられる，又ウサギの特徴として，束状層には可 染性顆粒が極めて少なく細胞基質の大部分は脂肪顆粒によって満たされている. ウサギでは束状愿深部にはラットやマウスで屢々観察された暗調細胞は殆ど評明 されないのである。Roaf (1935) はウサギの副腎皮質について㲔しく観察した が，やはり球状搫の独立性を信じ，束状層との連続性を指摘していない，私はウ サギをストレス実験に用いる場合上の種特異性を充分に考虑する必要があると思 う.

d) モルモット.

モルモットでは上述の諸動物に比して被膜は制合に厚く，それより此較的豊富 な結合組織が束をなして真直ぐに或は斜に皮質の中に侵入している，モルモット の球状層を様々の断面で眺めてみると, 系球を形成している様に見えるところも あるが，或る場合にはやはり束状層と球状蟹とが一続さであり，束状層がその まっ伸びて肥厚性細胞 索を屯って被朕に達し ているのが観察される (図 9). 然し乍ら凡て に於て上の関係怔実在 するとは限らないが, 恐らく斯加る移行関係 が可成り多数にのぼる ことは確かであろうと 考えられる。球状層に 单る上思われる場所を 詳細に検べると，矢㖘 り太い細胞索として伸 びているが，その方向 は量直のことも斜のこ とああり，それ等が入

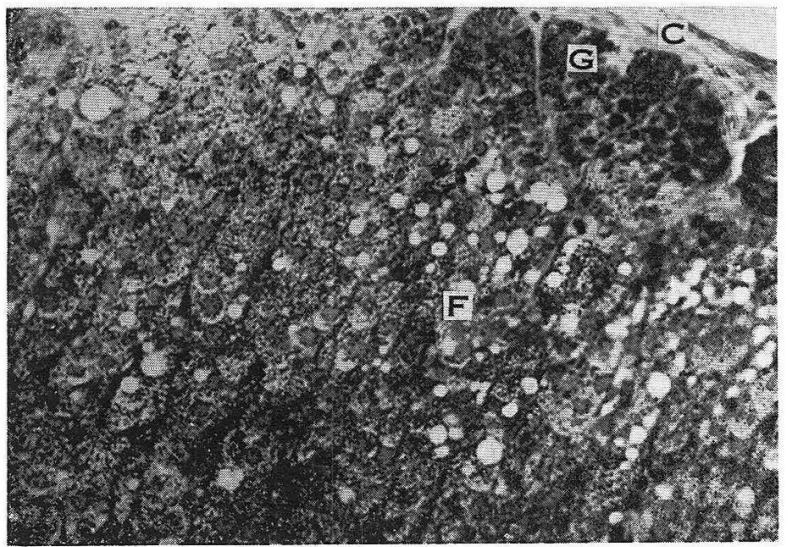

Fig. 9 Adrenal cortex of male guinea pig. The cell cords are prolonged to the capsule $(C)$ : Zona glomerulosa $(G)$ of this animal may be a presentation for the collection of extended cell cords of Zona fasciculata $(F)$, the transitional zone is not consequently observed between two zones. The occurrence of huge fat droplets is an impressive manifestation in Zona fasciculata. LEVI, iron-hemat. $\times 200$

り乱れて 3 次元の空間で交义しているらしい構成が理解される。モルモットでは 細胞索を被う結合組織性被膜は比較的厚く, 鉄へマトキシリンに強染する線維成 分を多量に含む。細胞の間には豊富な結合組織が存在し，こ〉に血管が直走する のが見られる。乙の結合組織は上述の被裳より派出された結合組織の分派であり， 被䐓より一定の距離までは即ち細胞索が様々のう向に表面に向って突隆する起始 部のと乙ろまでは深く侵入するものの如くである，從って言葉を換えて云えば， こっまでが厚い被膜であり，その中を束状層より多数の細胞索が登って来て貫通 
しているのがモルモット球状罾の真の栥ではなからうか，彷ってモルモットでは

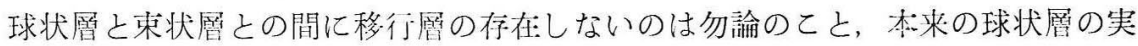
在性さ元も疑わしくなるのである。

次に，被膛直下に位する突隆している細胞索の最上端部をみると，明らかに基 底部に比して索自身が肥厚しており，被臊に接近して多数の核が密集している

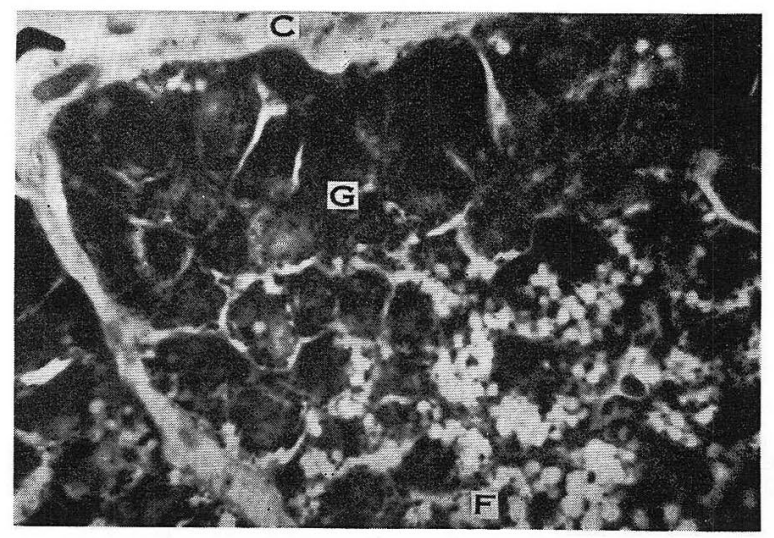

Fig. 10 Zona glomerulosa of male guinea pig. The cells are shadowed with the stainable granules and mitochondria, whereas those in Zona fasciculata $(F)$ hold a plenty of fat granules between which mitochondria are scattered. $C$ capsule, $G$ Zona glomerulosa. LEVI, iron-hemat. $\times 900$ ところがある(図10)。こ の部の細胞境界は不明膫 なことああるし，六大䉁： に於いて認められること あある．胞终には脂肪顆 粒は極めて少なく，あっ ても極めて小型のものし かない、ウサギに於ける と闹様この細胞の基底部 即ち核下部には多数の mitochondria と微細な可 染性顆粘が充渾してい る。核の密集部以外の場 所では脂肪顆校が徐々に 出現しはじめて来る。従 って被㮠に接した限呞性の場所は弱拡大で見ると，他部よりも暗調に見える，モ ルモットの球状層はこの様に境界が不明瞭であるので，何処を指すのかは判然之 しない. Bachmann (1939) は被膜の下にある暗調の部分を球状層と呼び, 被膜と この部分の間で新しい皮質細胞の形成が行われると説く所謂 Blastema 学説を樹 てたが，との暗調の球状曆は私の標本では核の密集部で脂肪顆粒のそしい細胞群 の存在場听に一致している。要するにモルモットの皮質の zonation は極めて不明 瞭であるととがわかる。

次に束状層であるが，被膜を離机て内曆に及べば脂肪顆粒は豊富になって来 る，束状層深層では脂肪顆粒は一般に大型のものとなり，巨大なものが時々出現 する。モルモットの束状層細胞の特徴は胞集が他の動物に比して一般に暗く，多 数の可染性颗粒が充満することである．往って可染性顆粒への脂肪粒子の沈着は 軽度であり，モルモットでは凡ての可染性顆粒が脂肪顆粒に転化するわけではな い，正常の条件即ち非ストレス曝露時には斯くの如く脂肪顆粒化が充分に行われ ないことがモルモットの特徵と云えるのである，從って前と同様可染性顆䊀 (masked fat を含む可能性はある) む steroid hormoneの担价であることは充分考 えられる。 
e) 八ムスタ一.

八ムスターの球状層も疑張り束状層と一続きであり，下より登って来た細胞乘 は被膜下で反転してドームを形成する如学配列を圭し zona arcuata の形を呈して いる(図 11)。 ハムスターではモルモ ットの様な受状唒列ではなく多数の細 胞が集まった太い細胞集団としてドー ム形成にあずかっている。それ故ての 部分が球状層に当ると考えられるもの の移行廨は矢張り八ムスターでも存在 しなく, 球状檿細胞はそのま〉束状櫫 に移行している，球状歷の部分を構成 する細胞は一般に難染性で, 辛うじて

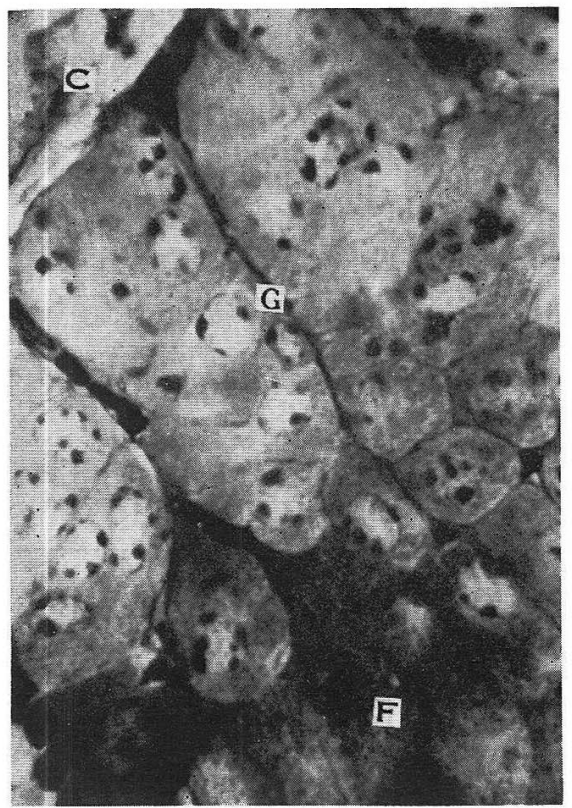

Fig. 12 High magnification of Zona glomerulosa of male golden hamster. The cells are approximately exclusive of granular elements and appear homogeneously, but in detail examination some delicate faintly stained granules and mitochondria can be recognized, while fasciculata cells are susceptible of having the accumulation of stainable granules. This animal is charactrized by the absence or excess reduction in number of fat granules in Zona fasciculata $(F)$. $C$ capsule, $G$ zona glomerulosa. LEVI, iron-hemat. $\times 900$

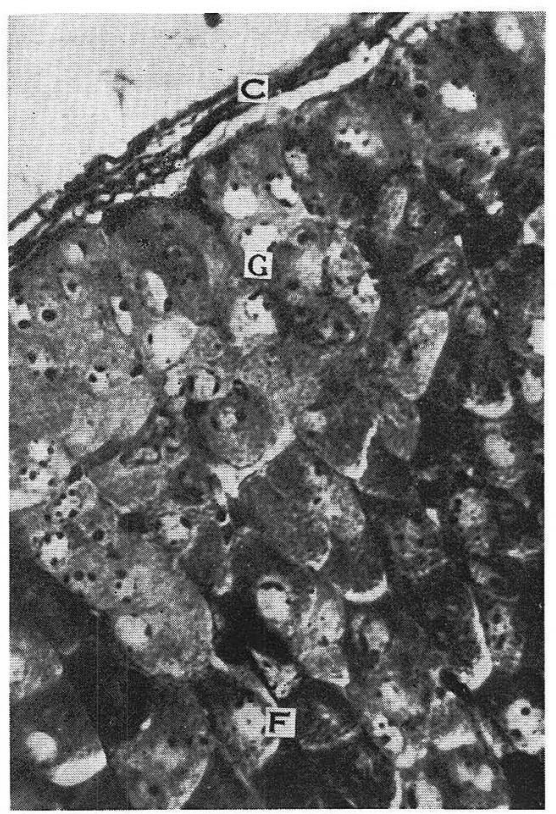

Fig. 11 Adrenal cortex of male golden hamster. Also the cell cords go upwards to reflect on the capsule $(C)$ with the consequent formation of Zona fasciculo-arcuata. The transitional zone is also absent. $G$ glomerulosa, $F$ Zona fasciculata. LEVI, iron-hemat. $\rtimes 400$

漏漫性に淡染し，原形質には脂肪顆料 が殆ど存在しないととが最あ特異的な 所㫕である（図 12）。その代り小さな 弱染性顆粒が多数様々の場所飞我朴 しているのが認められる。この様に steroid hormone の担焦と晃做されて いる脂䏳顆精が存在しなくても，八ム スターが明らかに常に塭類代謝異常を 起している動物ではないととから見て む, 失張り可染性顆粘がホルモンの担 椺であるととを示す一面の可能性が潜 んでいる。

次に束状層では細胞索は細くなって 
来て，典型的な束状配列を示す様になる。乙の細胞でも矢張り脂肪顆䉽は例外的 に僅かに存在するに過ぎない，その代り多数の mitochondria 之強染性顆粒が多 数認められる。乙れは球状層部の弱染性顆粒の豊蒚な出現と対蹠的である。斯く の如くハムスターでは皮質全層を通じて脂肪顆粒が少ない点は此較組織学的に誠 に興味ある事実と云わなければならない。

\section{f) 1 又.}

イヌの副腎は可成り厚い結合織性被膜により包まれている。イヌでは球状層と 束状層とは明らかに細胞配列に於ても形に於ても差異がある。球状層は zona arcuata を呈し，狭小な細胞より成る細胞索は被膜下で紘く反転してドームを形 成している（図 13），細胞索の外周は比較的厚い結合組織怡膜で境され，上皮索

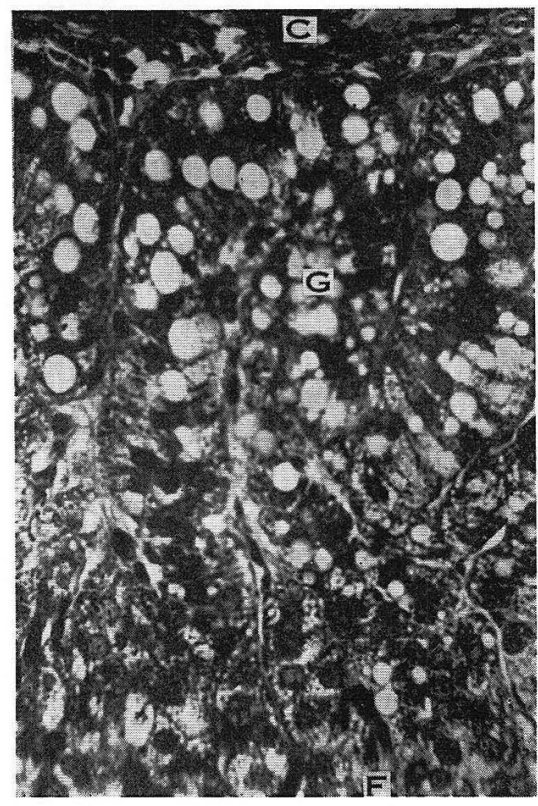

Fig. 13 The adrenal cortex of male dog. The typical arcuata formation is visible in Zona glomerulosa $(\boldsymbol{G})$ consisting of narrow and tall cells in which are interspersed some gross fat droplets. Zona glomerulosa is not completely independent by the connective tissue, but either gradually transforms into fasciculata cells or transmigrates inwards.

C capsule. LEVI, iron-hemat. $\times 400$
の基底膜の形態を保っている。 その反対 側で上皮に境する被膜は極めて薄く，光 学顕微鏡では解り難い場合もある。細胞 索によって国まれた山所を充たす結合組 織は狭小で，こ」に毛細血管が侵入して いる。球状層の扁平な細胞は厚い被膜 （基底膜）の上に縦に立列して並んでお り, 椟屯縦に押された様に扁平で, 細胞 の略々け尖部に住している。細胞が狭小 であるため 1 つの断面では核が重なって いる様に㫕える。細胞户には小さな脂肪 顆粒が様々な場所に豊富に存在し，又川 には核より大きな巨大な脂肪顆精が色々 な埸所に多数認められた。イ又では球状 層細胞内の可染性顆粒は一般に微細であ り数も極めて少ない。これは八ムスター 乞全く逆である。球状層の最下厤をみる と，急激に細長い扁平細胞はなくなり束 状層細胞に移行する。移行部には結合組 織性の隔膜はなく，急激ではあるが然し 細胞の一定の変形を伴なって束状層細胞 に移行するのである。即ち今まで扁平で あった細胞の幅が短縮し徐々に束状層細 胞の如き矩形を呈して来る。乙の様な場所は移行層と云えないとともないが，別 に特別な細胞層であないし，㕛特別の部位を独占するわけでもない，要するに漱 次的移行であり，特別な意味がある訳ではないと思う（図 13）.

次に束状㞛であるが，乙っでは球状層よりもずっと小さい形の正方形，矩形乃 
至不定形の細胞より成り，それらが大怜に於て規則正しい束状配列を示している. 胞你肉には球状屏と同様極めて多数の脂肪颗粒而も時に巨大な脂肪顆粒が出現し ており，乙れが束状層深層にまで及んでいる。一方叮染性顆粒は少なく，㷋って 出来上ってから時間の経過した標㭅では osmium 酸で黒染した脂肪が還元性を失 い，そのため度質の大部分は極めて明るく見えている。束状層の表腒部に zona spongiosa が限局しているわけでなく, 束状層全体が海綿質の様に見える. 暗調細 胞はイヌでは極めて少なく，皮質深層に限局して僅かに認められるに過ぎない。

\section{g) ネコ.}

同じ食肉類でもネコはイヌとは球状曆の形態が大いに異なる。イヌの様に非常 に細長の細胞から成る特有のドームの形成はみられず，八ムスターの如く束状曆 の続きである細胞索が上方に延びて被膜下で太くなり反転しているのである（図 14).乙れも zona arcuata の配列であると云えないことはないが，イヌとは大いに 趣を異にしている。ネコであ束状磨 と球状層とは一続きであるから，本 来の意味の移行皤を構成する異質的 細胞の集过は存在しない. 球状層の 細胞索の最尖端即ち被朕の直トでは 核が密集していることが萝い. 球状 層の細胞は境界が不明瞭であり, 細 胞は弱染性顆䊀を封含するが，脂肺 顆粒は表畨部では一般に少ないか或 は存在しないかである。この点イヌ とは大いに異なるわけである。被臊 を速ざかるに従い細胞は略々 1 列に 配列するようになり，㭙に互に吻合 する細胞索さなる。束状曆細胞には 脂肪顆精が極めて豊富である，従っ て脂肪顆粒の多塞は球状尿之束状層 とを区別する 1 つ目標とすること が出来る，さて両層の移行部在見る と本質的には別に束状屏細胞とは異 ならないが，内部構造がや」異なる 或万種の細胞が存在する。乙の細胞 には強染性顆粒がなく弱染性顆粒に

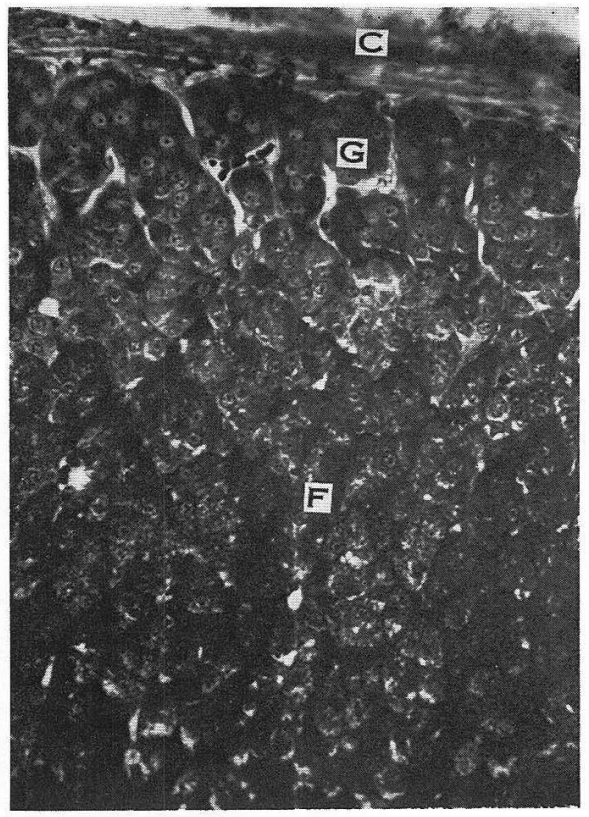

Fig. 14 Adrenal cortex of male cat. The animal dose not provide the same arcuata pattern as seen in dog. The cell cords of Zona fasciculata $(F)$ prolong themselves upwards to turn down from the capsule $(C)$, making irregular domes. $G$ Zona glomerulosa. LEVT, iron-hemat. $\times 200$

富むので, 球状層細胞よりはるかに明調に見える（図 15）。然し束状層表層の脂肪 顆粒が充満する束状層細胞 (zona spongiosa)に比べると, 脂肪顆䊀にそしいため にや〉暗調である。細胞は概して扁平なあのが多くて大小不同で核は娴形である。 


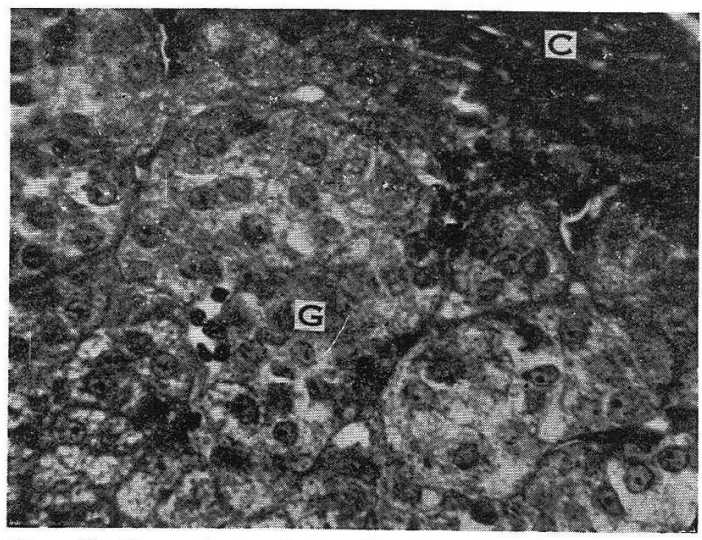

Fig. 15 Zona glomerulosa of male cat. The cells whose boundaries are obsecure are charged with delicate granules but poor in fat granule. Since evidence is present that glomerulosa cells may gradually acquir the fasciculata character, the transitional zone would be naturally negligible in this photograph. $C$ capsule, $G$ Zona glomerulosa. LEVI, iron-hemat. $\times 409$
Bennett (1939, 1940, 1941) は脂肪の少ない表層細胞を

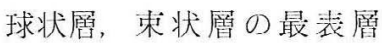
の別の細胞を presecretory layer，束状層上半の脂肪颗 精に富んだ層を secretory layer，後半の脂肪顆粘に昰 しい所老 postsecretory layer と呼んでいる、Bennett の 云う presecretory layer は球 状橎之束状層の移行部にあ たる埸所であろうと想像さ れる. Cater (1954) あこの 愿を移行層之考えているが， 私はこの層を本来の意味の 移行檿と呼心゙ないにしても，

要するに球状層と束状層との移行部にある漸進的川間型細胞である様に思う。束 状層の深愿では脂肪顆䊀が少数となることはBennett の指摘した通りであり，反 対に可染性顆䊀が多くなる。従って束状層後半は頗る暗調である。

h) ウシ

ウシの副腎は極めて 暻い結合織性被膜で被 われている。球状層を 形成する細胞集団の断 面が肥厚した被膜の小 に島状に散在し，この 中に埋没されている感 を呈する(図16)。島状 の糸球を構成する細胞 の数は不定であり, 叉 大きさむ種々である。 恐らく断面としての切 れ具合によるあのであ ろう。しかし標本の帒 々な場所でよく観察す ると球状層と束状層と が一続きであるものが

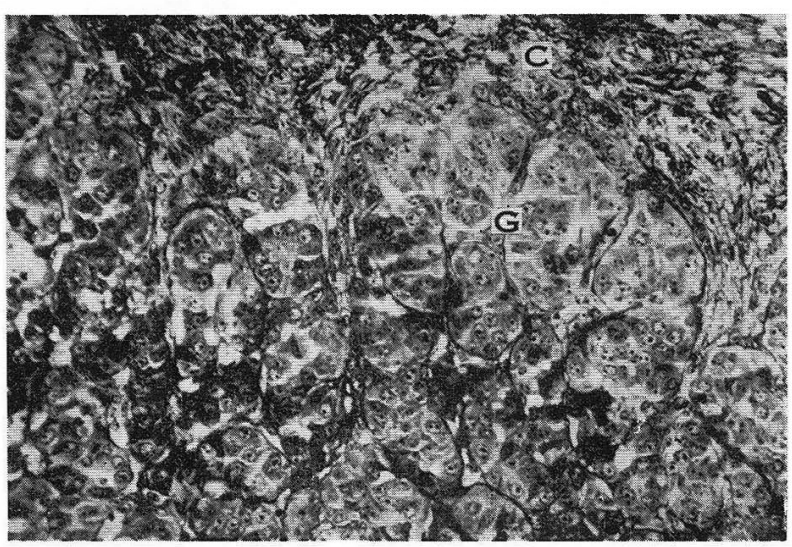

Fig. 16 Zona glomerulosa of ox. The extremely broad capsule $(C)$ is penetrated by the cell cords which, in a cross-section, appear to be enclosed with the thickened basement membrane. However these cords are responsible for the prolongations of Zona fasciculata, and therefore the possibility of a common continuation of two zones would be consolidated. $G$ Zona glomerulosa. LEVI, iron-hemat. $\times 200$ 
ある。勿論すべての場合ではないが，ての事実から判断しても，球状層と束状層 とは矢張り一続きであることが推察できる. 球状層の細胞は境界不明暸であるが, 胞作内には大小不同の脂肪顆䊀が少数ながら存在するが，決してイヌの如く豊富 ではない，その代りに強染，弱染性の两顆粒が比較的多く存在し全体が暗調を旺 している(図 17). 全般的に球状層の細胞索はそんなに太くはなく，寧ろ他の動物 に比して細いようで ある。束状層がその ま〉上方に或は，斜 上うに伸び愿い被牊 の内で様々の高さで 盲端をあって終って いる。行ってある断 面では上の如く島状 の孤立性分布を宗 し, 個々の糸球とな って現われるのであ 万う。㕛稀れに zona arcuata 状の配列を 亦すことあある。

次に束状層である

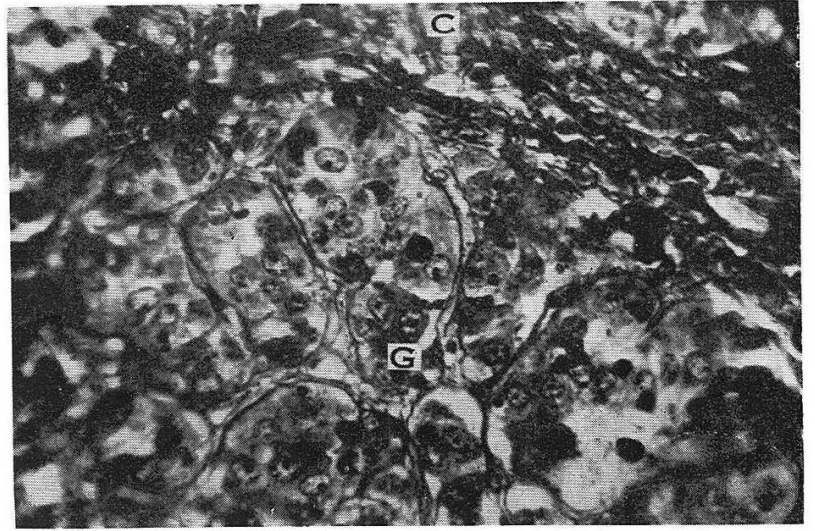

Fig. 17 Zona glomerulosa of ox. A cell mass surrounded by the basement membrane represents the glomerular appearance in which cellular ellements contain several number of gross granules, not associated with fat granules. $C$ capsule, $G$ Zona glomerulosa. LEVI, iron-hemat. $\times 400$

が，比較的細い細胞索が束状に配列している，こ〉の細胞には弱染性顆粘が極め て多く存在するが，脂肪顆粓が少ないとよが特徽である，徒ってウシの皮質細胞 は一般に暗調を呈している.

\section{i) ブタ.}

ブタの副腎の被膜もやはりウシと同様厚い，球状層は束状層より突隆する細胞 索の続きであるととは前之同様である。ウシと同様, ブタの標本を観察すると厚 い被膜の内で上皮索は様々の高さの盲端をもって終っていることが理解される。 上皮索は不規則な突隆であるので様々の断面を呈する細胞集団として現われる （図 18）. 又上皮索は盲端に終ることなく反転して元にもどる所謂 zona arcuata を 形成するむのも時に見出される，要するにブタでむウシでも球状層と束状層とは 一続きであり，その間に移行層は認められない，嬮い被腼の中に散在する球状層 の断面は，束状曆の延長である細胞索と同じ位の太さである，然し球状層では比 輍的核が密在する傾向がみられ，糸球を構成する細胞の境界は全く不明暌であり， 胞体内には脂肪顆粘は殆どないか，あってあ極めて少数である．乙れに反し可染 性顆粘は比較的多数に存在し, そのため細胞は暗調を呈し一般に瀮漫性に淡染し ている，一方束状層は皮質の大部分を占める厚い層で，束状を呈する細胞索は互 に不規則に吻合し合う様に思われる。束状層浅層の細胞は深層のものより比較的 


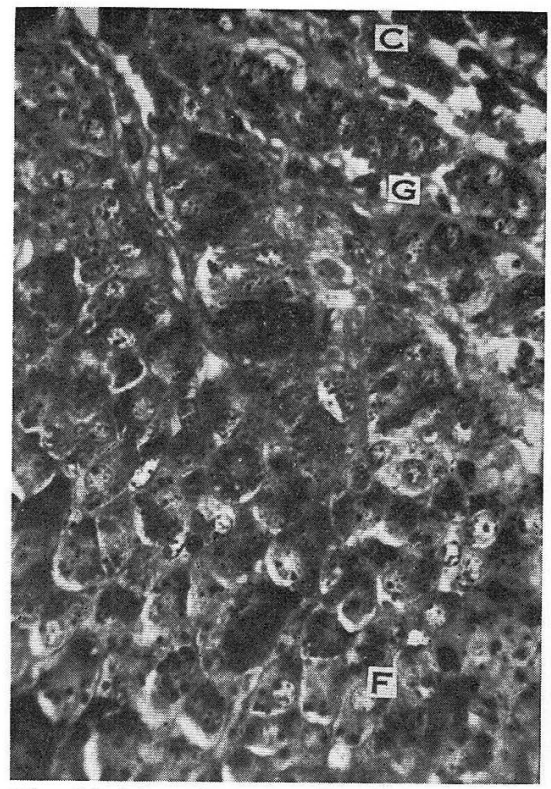

Fig. 18 Adrenal cortex of male pig. As the cell cords form fasciculo-arcuata pattern beneath the capsule $(C)$, the Zona glomerulosa $(G)$ and fasciculata $(F)$ is together combined. The cellular arrangement and its internal structure in both zones resemble those in ox. This animal is characterized by the occurrence of abundant stainable granules, instead of fat droplets. LEVI, iron-hemat. $\times 400$

層とは形態的にも細胞限列の点でも全く 異っており，それ故すべての点でイヌと 似ているのである。球状曆細胞の境界は イヌと同様此䡥的明睹で庄迫された様に 扁平且つ細長であって，核もこ机に心じ て扁平である（図 19），細胞が狭少であ るため，核が密集している様に昌える. 原形質内には脂肪顆粘が㓶合に多く認め られるが，イヌよりははるかに少ない． 核は細胞の基底側即ち厚い被膜に近い部 分，或はその反刘極の方に出現して一定 しない(図20)。一方この細胞には可染性 顆精も此較的多く見られるがこの点もイ 又とは趣を異にする。球状層と束状層と
大きい，細胞体内には微細な弱染性顆粒 が概ね充満し，比軖的粗大な脂肪顆粒む 全束状層にわたり数は少ないが認められ る，徒って zona spongiosa と称せらるべ き曆はブタにはなく，総售的に束状層の 脂肪顆粓は少なく細胞は暗調を呈してい る。乙の点ウシと似ている。

\section{j）ウマ.}

ウマの皮質を被多結合組織性被膜は極 めて厚く, 結合組織線維が密に配列して いる。 Bachmann (1941) によれば内に平 滑筋線維を認めるという。ウマの球状層 はイヌの如くに fasciculo-arcuata の形態 を示している．即ち細長い扁平な細胞か ら成る細胞索が馬蹄形に被㹸直下で彎曲 して反転している，從って球状層と束状

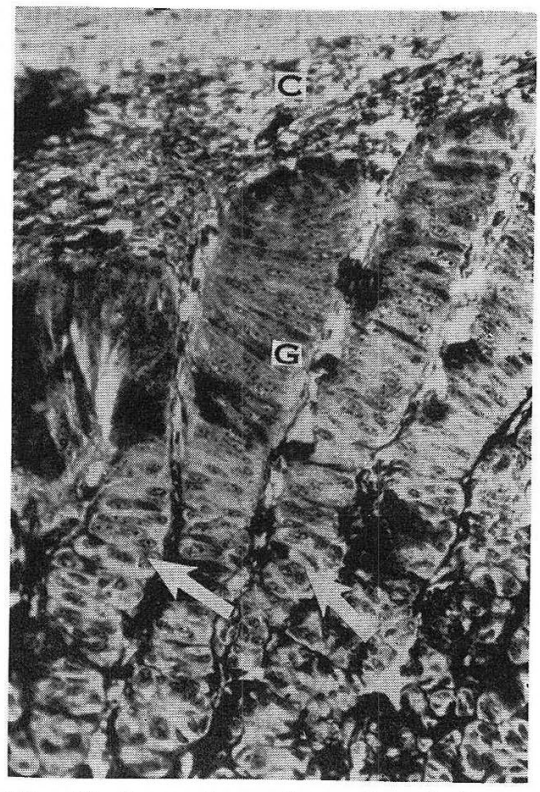

Fig. 19 Zona glomorulosa of male horse. Fasciculo-arcuata pattern similar to those in dog is shown. The narrow and elongated cells are gradually altered in shape to gain fasciculata cell nature (arrow). $C$ capsule, $G$ Zona glomerulosa. LEVI, iron-hemat, $\times 200$ 
の中間部には両者の何 れに属するとも区別し 難い一定の細胞がある （図 19）. 即ちこの細胞 は徐々に檿さをもつに 至り，長さむ滅じて束 状噟細胞に近くなる。 この細胞の脂肪顆精は 一般に少なく而も小形 であって，又弱染性顆 粒が少数ながら認めら れる。中には多角形の 細胞も現われ，不規則 な無秩序な配列を示す

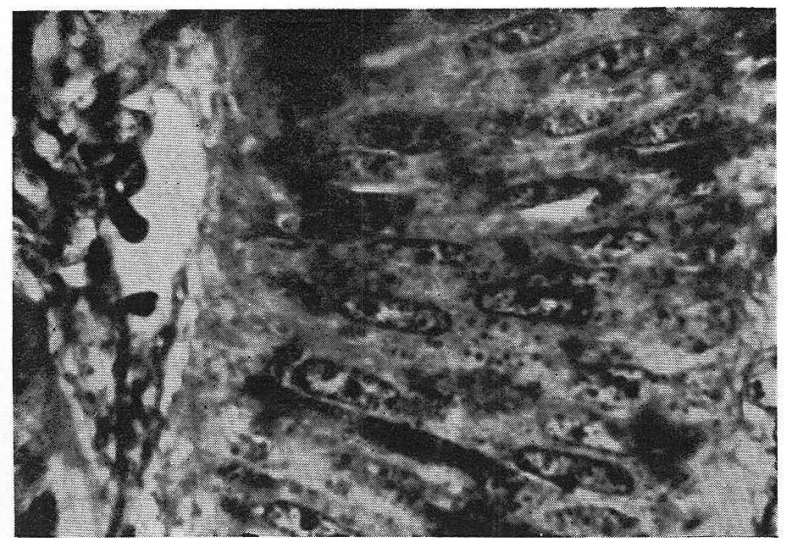

Fig. 20 High magnification of glomerulosa cells in male horse. The narrow and elongated cells include numerouse stainable granules but fat droplets in contrast with the converged deposition in dog. LEVI, iron-hemat, $\times 900$

所もある。この細胞層は確かに移行曆と云えないことはないが, 然し移行勫が球 状層と束状勫とを完全に遮断する隔壁を作る様なことはなく, 要するに球状層が 徐々に束状愿に変わる漸進的移行像を示すに過ぎないと想像できる。束状層では 細胞は典型的な細胞索を作り真直ぐに队方に伸びている，束状層表層の細胞は深

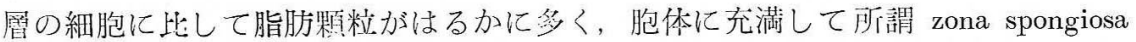
の形態を俏えている，脂肪顆校の閒には mitochondria と微細な可染性顆䊀が豊富 に認められる。束状層深部では脂肪顆精の出現頻度は小上なるが，存在する時は 大体大きいものばかりである。一方微細な可染性顆䊀は更に豊富となり胞倈圭満 し，暗調を呈している。

k) ヤギ.

ヤギの副腎む厚い結合組織性被膜で囲まれている。球状層はブタと同じ様に束 状層が上方に伸びて出来たものであり，ウマの様な紐長な細胞から成立っている わけでなく，束状曆がその䱾球状層の估置を占めている如く思われる。こ〉でも 被膜下で肥厚して核の密集部を形成するが，こ」で盲端を以って終る場合と，反 転してドームを作って再び下降するむのとがある（図 21），反転場所が被裳の最 上方である場合は分離独立した糸球となって現われるのであろうと想像できる. 次に球状尿細胞の境界であるが, 矢張り不明瞭であり, 被膜の直下には核の密集 部が見られる。球状層には脂肪顆粒は少なく，その代り mitochondria と可染性 顆粒が可成り認められる（図 22）。一方束状層は此較的細い細胞索を形成してい るが, 球状層と束状層との間には別に劃然たる移行層は存在せず徐々に束状層に 変化して行く（図 21）。ヤギでは束状層細胞にも脂肪顆粓が殆ど存在しないこと が特徴であり，ての点八ムスターと類似している．脂肪顆粒が全く存在しないと 云うわけではなく，稀れに小さい脂肪顆粒が残っている。乙れに反し可染性顆粒 


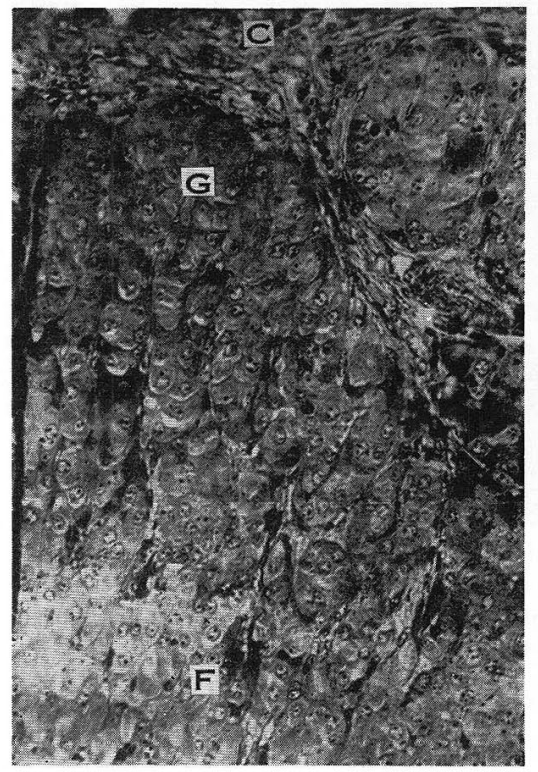

Fig. 21 Adrenal cortex of male goat. Also Zona glomerulosa $(G)$ and fasciculata $(F)$ have a reliable continuation which results in the absence of transitional zone. The goat is characterized by the unapparent zonation in the cortex and the lack of fat granules within the cortical cells. $C$ capsule.

LEVI, iron-hemat. $\times 200$

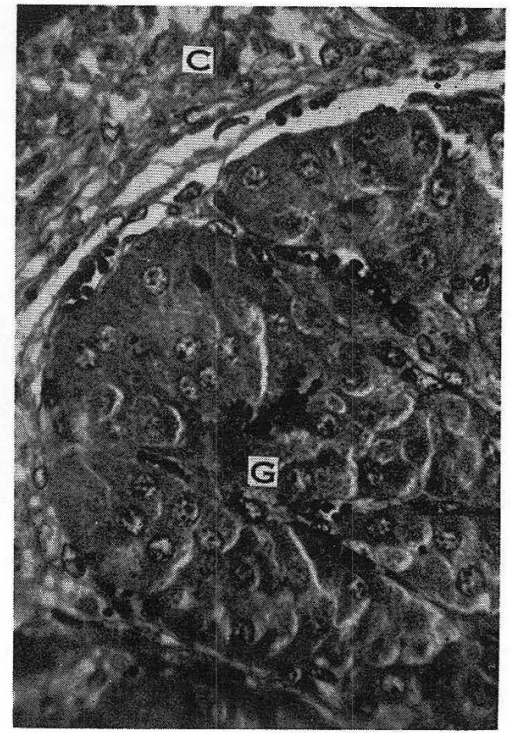

Fig. 22 Zona glomerulosa of male goat. The dome is visible beneath the capsule $(C)$; its constituents devoid of obvious outlines are charge with fine granules, sometimes simultaneously contain a few gross granules, but do not fat droplets. G Zona glomerulosa. LEVI, iron-hemat. $\times 400$

は常に豊富であるが，然し人きさはそんなに巨大にはならない．可染性顆椟から 脂肪顆粒が出来上る可能性は前述の諸動物に於けると同様であるが，この脂肪化 がヤギでは余り進展していないのではないかと思う。従ってての動物では可染性 顆料の内の脂質はあく迄も masked fat であって，このととは steroid hormoneの 需要が少ないためか, masked fat の中に充分な steroid hormone が含まれていて 貯蔵型である脂肪顆粘にならなくてもすむか，何れかを意味する様に思う。

\section{III. 考 察.}

球状層は副腎被㮠に続く副腎皮質の最外層で，度質細胞が系球状に配列する場 所である。貧弱な結合組織性被膜で囲まれた各々の糸球を構成する細胞の境界は 比較的不明暸であり，核の密集部を形成している，その典型的な像を私はラット に於て見た。然し私が幾つかのラット副腎皮質の標本に就いてしらべた結果，典 型的な糸球形成がなく, 球状層と束状層とが一続きの細胞索であることが可成 りの頻度に於て存在することを確かめた，既に述べた如く，球状層と束状層とは ラット以外のすべての動物に於て一続きの様であり, 從来の報告では多くの動物 
で両層の断続性が指摘されているが, これは 1 つの断面によって判断したためで, よく観察すれば，1つの標本でも両層が連続していることは確実に証明されるの である（図 23）。唯動物によって上方に登る上皮索が比較的真直ぐに配列するむ の之, 相当に不規則で互の吻合, 彎曲等が恐らく存在する動物とがある. 前者で は 1 つの断面であ明らかに両層の連続性を証明出来るのである. 私はその代表と してウサギを挙げることが出来ると思う.

Rotter (1949) は幼若哺乳動物には未だ真正の球状層が垫化していないととを 指摘している，彼によれば下より伸びて来た皮質の細胞索は被䐉にまで達し，乙 ১で弓状に彎曲して元に向って放射状配列を示すと云う。更に彼は幼若哺乳動物 の皮質の外層は zona fasciculo-arcuata の形態を備えると云い, 一方球状層は生後 一年の間に外層即ち被膜下で生成されるもので, 生後 3 ケ月以後出現すると述べ ている、私がウサギに於て見た球状層の細胞配列は幼若哺乳動物に見られる zona fasciculo-arcuata に一致する形態を備えるものであり，彷ってウサギの副腎皮質外 層は分化が遅れた未熟の状態に停つているあのの代表と考えられる. 然し一方, ラットをストレスに曝すと球状層が压迫され被膜の直下に残存するのみで下から 束状層が伸びて被膜に達するととが Yoshimura（1954）によって報告されている. この時の細胞配列は明らかに皮質が 1 つの細胞索によって貫かれているととを示 しており，或る程度ウサギの細胞配列と似てくる．從ってウサギは球状層が恒常 的な配列ではなく，ストレスに対して感受性が高く，常に副腎皮質は機能六進像 を示していると解釈出来ないことはない.

次に移行層について考察してみる. 前にも言及した如く, Cater と Lever (1954) はラット，ネコ,イヌ，ヒッジ，ウサギ及びウマでは移行層ははっきりしており， モルモット，マウス，雌ウシ，ブタでは容易には見られなかったと述べている．移 行層は別命 sudanophobic zone と屯云われ, Sudan III に可染される脂肪顆粒の全 くない層であるが, Yoshimura (1954) はラットに於いて osmium 酸に反応する脂

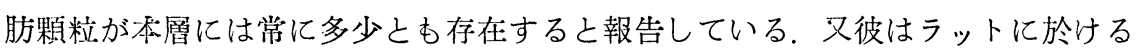
移行曆を次の如く定義した. 1. 移行層の細胞は扁平な細胞で, 2. 横に長軸を持 つ長符四形の核を有し，3. 細胞境界はや〉不明瞭であり，4. 細胞質に多数の弱染 性顆粒が見られるが，強染性顆粒は殆どなく，6.乙の細胞層は $2-3$ 列に並び球 状層と束状層との間を横に走っていると述べている. 今回の此較組織学的観察に よれば，上述の定義を満足する様な移行層が存在したものは矢張りラットのみで あった，但し球状層と束状層之の中間には何れの層に附属するか不明であるよう な中間的細胞層が存在することがネコ, イヌ, ウマ等で観祭された, それらの細 胞はその形, 内部構造が両厤の細胞の中間に位し, その間に漸進的な変転が認め られるのである。從ってそれ等の動物の移行層は特別の細胞層ではなく, 一続き の細胞索に於ける上位と下位との質的差異がこの部に於いて現われて来たと解釈 出来る。然し副霜皮質の中でも移行層には最も著明な性差が現われることが知ら 
Rat

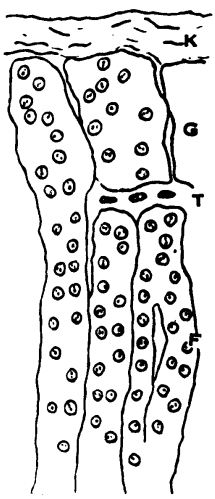

Guinea pig

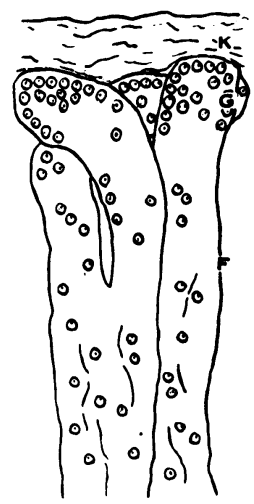

Mouse

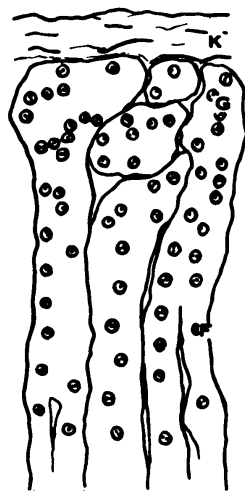

Hamster

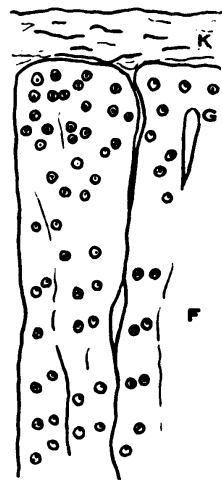

Rabbit

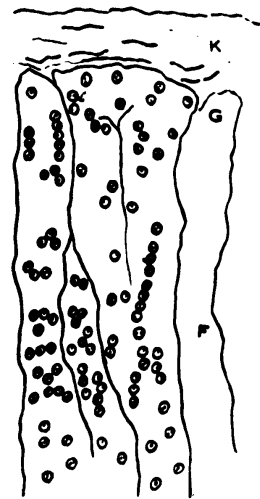

$\operatorname{Dog}$

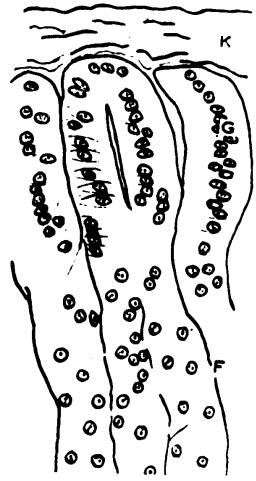

Fig. 23 Diagrams demonstrating the interrelationship of Zona glomerulosa to the Zona

れている，未成熟の雌雄ラットでは殆んど例外なく移行層は存在すると云う意見 があるが (Greep と Jones 1950), Tadokoro (1954) は雌雄成熟ラットでは移行層 が不完全か, 或は萎縮または消失するものと述べており, 移行層の出現之性腺機 能との関係を重視している，雄ラットに高頻度に存在する移行曆は去勢により消 失し, 雌ラットでは反対に卵宩剔出によって出現するが, estradiol 投与により消 失し (Gaunt 等 1953), testicoid 投与により出現する (Greep と Jones 1950) とも 云われている。等性腺因子が $\mathrm{ACTH}$ 放出之如何に関係するかは明らかでない.

副腎皮質の細胞は被膜のすぐ内側で新生され，乙の屯のが皮質の外方から内方 に向って移動すると考えられているが, 之は Gottschau (1883) の Blastema 学説 とも云われる. Salmon, Nussmann, Zwemer (1941) はラットの腹腔に trypanblau を注射し，各層に於ける皮質細胞に現われる色素顆粒を指標として細胞の移動時 間を計算して Gottschau の細胞移動説へ支持を与えた。吉村（1955）む正常モル 
Cat

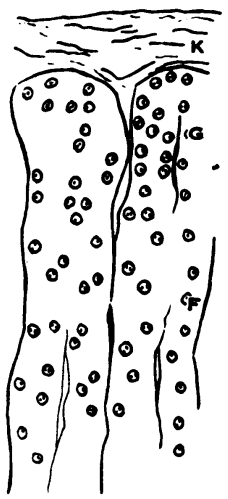

$\mathrm{Ox}$

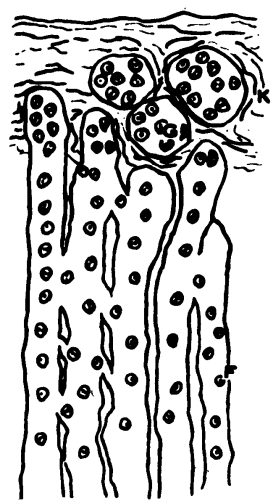

Pig

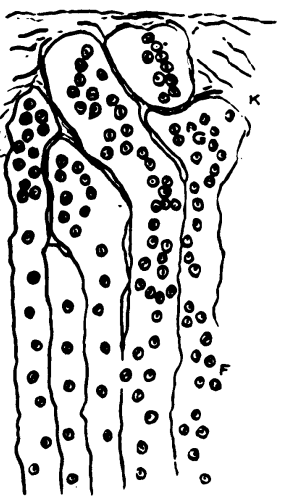

Horse

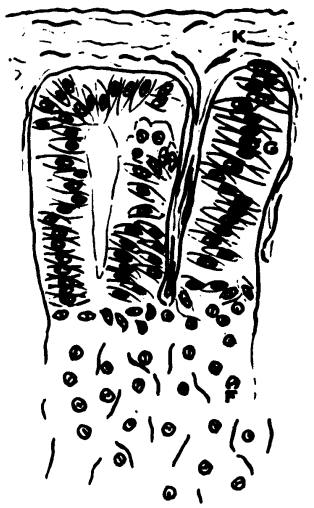

Goat

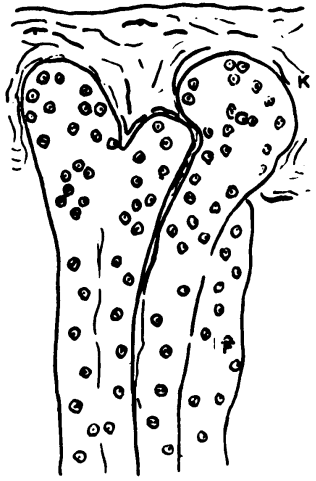

fasciculata. $K$ capsule, $G$ Zona glomerulosa, $T$ transitional zone, $F$ Zona fasciculata.

モットの球状層表層に見出される幼若な細胞は恐らく fibroblasten より由来する あので，乙のあのから球状層細胞が新生されるものとの考えに傾いている，教室

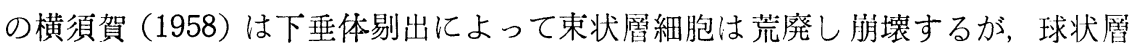
は余り变化を蒙らない。しかし剔出後の時間の経過と共に配列及び細胞の内部棤 造の上でむやがて束状層と同じようになり, 形態学的にも積極的にホルモンの合 成と放出とが営まれていることを思わしめるに充分な像を呈すると述べ，その絬 果球状層の自律性を推定した。垂体よりの ACTH 放出がなくても, 球状層は 肥厚し副腎皮質の主要な層を形成するのであり，荒癈した束状層に於けるホルモ ン分泌を補足するのであ万うと推定したのである，彼は一続きの副腎皮質の細 胞索より糖質及び鉣質コルチコイドが同洔に出される可能性があると述べて, Deane, Greep と Shaw (1948) の 2 元淪に懐疑的である.

最近 2 元論に対立的な報告が多数出される様になった。 Jones (1949) は Deane 
一派の実験には昔から批判的であった。即ち彼は球状層が下垂体には比較的依存 していない層であることは認めながらも，同時に球状層細胞内の脂肪顆粒の消長 はACTH によって調節されることを肯定していた。.Jones と協力者（1954）は副 腎皮質の zonation と function に関する 4 篇の論文を発表した。 下垂休剔出80日 目のマウスは $\mathrm{Na}, \mathrm{K}$ の摄取と排出とは正常動物と同じレベルであり，下垂体剔 出動物であ塩類代謝に関する限り正常の能力が維持されている．然しての動物に $\mathrm{ACTH}$ を投与すると球状層が正常の大きさにもどるから，球状厥は ACTH と無 関係ではあり得ない，又 enucleation を行った後副腎皮質には決して球状層が形 成されず，日数の経過と共に束状を呈する細胞索が內腔を埋める様になる，副腎 摘出動物は自由に食塩水と水とを同じ歩調で攝取するが, enucleation 後に細胞が 新生されると動物は食嗑水を避けるようになり，ACTH を enucleation 後のラッ 卜に投与すると余計束状配列は典型的になる。即ち球状層は決して再生しないが, 電解質代謝は立派に調節されているのである。更に Diabetes insipidus に陥った ラットの副腎では球状層は㹨少となったが，それ以下は反って厚くなった，以上 のことから彼等は球状層は塩類代謝ホルモンだけを分泌するとは考えられない. 恐らく束状層が皮質ホルモン全般に互って分泌の責任をむつあのであり，球状層 は細胞自身の植物性活動力に基づいて，下垂你を離れて独立的に恐らく少量の木 ルモンを分泌するであろうと述べている，而も下垂体より ACTH が放出されな い時にのみ球状曆細胞の活動力が推進されるのであって, ACTH の循環量が增大 すれば球状層は束状の配列を亦し，循環量が元に戾れば再び球状愿の形態を俏え るに至ると云う。尚彼は blastema 学説を認めても, 移動学説には批判的である.

更に 2 元諭に批判的である意見として Knigge (1954) は DCA 投与によって球 状層には組織化学的変化がないとと, Wexler とRinfret（1955）は下垂体剔出ラ ットに ACTH を注射したが，その注射量によって球状層が受ける反応態度が著 明に相異するととがあると指摘し，球状曆も $\mathrm{ACTH}$ によって調節されると見做 した。そればかりでなく下垂㑂剔出によっても電解質代謝ホルモンの分泌が抑え られることが次第に主張される様になり，形態学的にも，化学的にもそれを示す 本実が報告されている．即ち Rauschkolb 等(1956)は下垂体剔出イヌを用いて研 究したが，副腎の萎縮は球状層に波及しないにも拘わらず， aldosterone の分泌 速度は対照群の約66\%に低下していることが知られ, Muller 等 (1956) と Lever (1956) は ACTH 投与によって aldosterone が放出されることを訳朋し，球状層細 胞の mitochondria が増加するとと，又それらへ脂肪粘子が沈着するてと等を電子 顕微鏡によって確めた。 又培養副腎皮質の基質のやに ACTH を混入した Giroud 等（1956）の研究によれば, aldosterrone 分泌を促進せしめた。

最近Orti 等 (1957) は $\mathrm{NaCl}$ を禁じたラットの尿から aldosterone 刺激物質を 直接取り出すことに成功し，乙れを注射すると aldosterone 分泌を促進せしめる と述べている，以上の外にも多数のてれ等 2 元䜽に対立する意見があるが省略す 
る (吉村 1959 を参照)，要するにこれ等の事実に照しても，副腎皮質の機能を球 状層と束状層の部位的差異によって分けることはや子早計であり, 機能局在論に は未だ検討の余地が大いに残されている。私の此較組織学的研究は, 多くの哺乳 動物の皮質細胞の細胞配列は杏来一続きの上皮索を形成するあので, この種の形 態こそ urtypus であると見做すととが出来ると云う結論に達した．私の観察は七 トとラットで樹立された Elias と Pauly の学説を多くの哺乳動物に於て同様承認 すると云う立場に立っている。

\section{IV. 総 括.}

健康と思われる雄性成熟ラット，マウス，ウサギ，モルモット，八ムスター, イ ヌ,ネコ, ウシ, ブタ, ウマ, ヤギの副腎をLevi 氏液とZenker-formalin とで固定 し, Heidenhain 氏鉄へマトキシリン染色を行い，贤質球状層と束状層との関係を 細胞学的に檢討し次の紏界を得た。

1.ラットの球状層は典型的な糸球 (glomerulum) を形成し, 内に境界不明の多 数の細胞を入れる。束状層との開には形, 内部構造の異なる細胞からなる $2-3$ 層の細胞檿即ち移行層が認められる。しかし完全な閉鎖性の層ではなく，听々で 欠損部をむっている。乙っでは束状層が真直ぐ伸びて被膜に逹しているから，球 状層とは一続きである，球状層表層部では糸球は幼若で $2-3$ 個の細胞から構成 されるあのが見られる。この種の細胞は脂肪形成が不活潑であるが，球状層の深 層と束状懕の表層とは脂肪顆粒が最も多い (zona spongiosa). 以下述べる諸動物之 此較すると，典型的な移行層が存在するのはラットのみであるととを知った。し かし本層は完全な sudanophobic zone ではない。

2. マゥスの球状懕では糸球の横断面は余り多くは見届けられない，多くは束 状層と一続きであり，細胞掌は被膜下でドームを形成してから反転し，zona fasciculo-arcuata を形成する。 その閒に移行層は存在しない. 各層の細胞の内部構造 はラットと似ている。

3. ウサギの球状層は最早その名に值しない，即ち束状層が真直ぐ上方に伸び て被償に達し，反転して下方に戻る。乙れも zona fasciculo-arcuataである. 從っ てウサギでも移行層が全く認められない，しかし細胞索の上方では核の密集部が $2 つ$ つっ, 此等が並列して皮質を横切っている，特に被䐉直下の密集部では細 胞の基底部に mitochondria や微細顆粒が密集しており, 脂肪顆粒は少ない。し かし他の部分の皮質細胞では極めて脂肪顆粒が多く，之に反し可染性蛋白顆䊀は 僅少である。又束状層深層では暗調細胞がそしいことあウサギの特徴である。

4. モルモットでは被兽が厚く, 束状層より上方に登って来た細胞䒺が斜に或

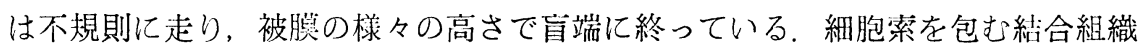
は比較的厚く被膜から可成りの深さまで入り込んでいる。彷ってモルモットでも 本来の移行層の存在は疑わしい，度質細胞には脂肪顆粒が少なく，但し大きいも 
のが疎に出現するが，反対に可染性顆䊀は豊富であり，細胞全体が暗調を呈する ことがモルモットの特徴となっている。

5. 八ムスターでも束状層と球状層とは一続きであり, 下から登って来た細胞 索は被膜直下で反転してドームを形成して zona arcuata の特徴をもっている。乙 の部の細胞索は太く，多数の細胞の集団を形造る，極めて難染性であって脂肪顆 粒を殆ど含んでいないが，弱染性顆粒がてれを補って豊富である，細い束状層の 細胞索でも矢張り脂肪顆粒が少ない. この点は, ホルモンの唯一の担侭としての 脂肪顆䊀に関し 1 つの疑問を投ずるものである.

6. イヌの球状層は zona arcuata を形ー゙くるが，その構成細胞は細長で特別の 形態を有し，㤟富な脂肪顆粘を含んでいる．球状層之束状層の間には漸次的移行 があり，その閒に独立した細胞層は認められない，束状層の細胞には八ムスター， モルモットとは異なり脂肪顆粘が豊富である。

7. 同じ食肉類でもネコの球状層はイヌのそれとは様子が異っている，てっで は前に述べた多くの噄㗀類と近似し, 束状層がそのま〉上方に伸び, 被膜の直下 で核の密集する盲端となって終っている，而もそこでは脂肪顆粘が少ないてとも イヌとは逆である。一方束状層には脂肪顆粒が豊富である。束状層と球状層との 閒には夭張り川間的段階に当る細胞が存在し，その漸次的移行を恋す様である.

8. ウシの被膜は甚だ厚く，その巾で下から上って来た細胞索が終っている. こ〉には可染性顆粒が多く，脂肪顆粒がそしいため暗調を呈する。 ある断面では 恰む島の如き観を呈するが，しかし実際は束状層細胞索と一続きであると考えら れる根拠がある．ウシの束状層でも知張り脂肪顆䊀にそしく，その代り可染性顆 粒が多数みられる。

9. ブタの副腎皮質もウシとよく似ており, 球状層の構成もそれと一致する。 皮質細胞に脂肪顆䊚の少ないとともウシと同様である.

10. ウマの球状層はイヌと似ており, zona arcuata を形成している。 その細胞 は細長であるが，イヌで見られた如く脂肪顆料は多くなく，可染性顆粒が一般に 豊富である。束状層との閒には矢張りイヌで見られた様な漸進的移行が見られる。 束状層細胞は一般に小形で脂肪顆粘にそしく，可染性顆粒が胞保を満たす。しか し束状層表層にはいわゆる zona spongiosa に当る脂肪顆粒の充満する層を区別で きる。

11. ヤギの球状層はウシ, ブタと大体に於いて一致する構造を示し, 束状層が そのま〉上方に向い様々の場所で盲端をもって終っている，てっでむ知張り球状 層との間に移行層は存在しない, ヤギでは球状層, 束状層共に脂肪顆精が殆ど存 在しないのであって，ての点は八ムスターと共に重要なる特徴となっている。

終りにのぞみ，御㸸篤なる御指導を賜った吉村不二夫教授に感謝致します。 


\section{Summary.}

With the materials of healthy adult rats, mice, rabbits, guinea pigs, golden hamsters, dogs, cats, oxen, pigs, horses and goats, cytological observations were made to examine the interrelationship of Zona glomerulosa to Zona fasciculata. The adrenal glands were fixed with LEVI's solution and serial sections stained with HEIDENHAIN's iron-hematoxylin pretreated with RUBASCHKIN's bleaching procedure. The results obtained were as follows.

The typical glomeruli consisting of numerous cells with obsecure contour occupy Zona glomerulosa of rats. The basement membranes enclose the glomeruli to make them independent; the intermediary or transitional zone which is regarded as the particular layer composed of a few ranges of dark shrunken cells is situated between Zona glomerulosa and Zona fasciculata. This zone is not a comprehensive closure membrane, but has many defects through which the cell cords ascend perpendicularly to the capsule with the consequent combination of Zona glomerulosa with Zona fasciculata. At the uppermost area of Zona glomerulosa are present small glomeruli which consist of a few cells appearing to be too infantile to synthesize fat granules, whereas a mojority of cells were loaded with fat granules both at the deepest area of Zona glomerulosa and at the upper part of Zona fasciculata (designated as Zona spongiosa). In comparision to the other animals which will be described below, it has been learned that the transitional zone would be merely inherent to the rat, despite it is not a complete sudanophobic zone, but contains constantly much or less osmiophilic fat granules in objection to the appointment of previous investigators.

In Zona glomerulosa of mice there were observed the reduction in number of cross-sections of the glomeruli. This would be referable to the fact that the cell cords of Zona fasciculata go upwards to the capsule and reflect down, presenting the fasciculo-arcuata pattern. Therefore these arrangements can precisely account for the absence of particular transitional zone. The cell cords and their internal structures correspond approximately in many respects to those in rats.

Zona glomerulosa of rabbits is no longer worthy of its designation, since the cell cords protrude to the capsule and turn in forming a dome conditioned on the development of Zona fasciculo-arcuata. It was our common observation that the adrenal cortex of rabbits is lacked with the transitional zone. Under detail examination, however, we could enumerate two special layers shadowed with granular elements: The one is an immature cell layer connected to the capsule, in whose cell basement were deposited abundant minute granules and mitochondria, and the other is a dense cell layer consisting of a mass of nuclei whose cytoplasm is also charged with the faintly stained granules. Two layers were susceptible to be distributed transversally in parallel to the capsule. The rabbit is characterized by the numerous fat granules and by simultaneous deficiency of stainable ones in all cortical areas but those in above layers.

The cell cords of Zona fasciculata in guinea pigs protrude irregularly upwards and terminate into the wide capsule at various places as the blind tips. The thickened basement membranes surrounding the cords are presumably originated from the ramifications of interstitial tissues of the capsule. The transitional zone does not take 
places anywhere in those cords. It can be considered to be the features provided with the guinea pig that the cortical cells contain abundant stainable granules instead of fat droplets with the exception of occassional occurrence of huge fat droplets. This is followed by the acquirement of their dark tone of cytoplasm.

In golden hamsters it was apparent that Zona glomerulosa is involved in a mass of projections of the cell cords of Zona fasciculata. Beneath the capsule the cord forms a dome responsible for the development of Zona arcuata. The swollen tips of the cords are masked with the delicate granules in spite of absence of fat droplets. In particular, the cells of slender cord in Zona fasciculata are also burdened with stainable granules but avoid of fat droplets, too. This would cast a doubt upon such a concept that the vechicle of hormone is nothing but the fat droplet in cortical cells.

Zona glomerulosa of dogs shows the strange appearance of Zona arcuata, whose cellular constituents usually extremely elongated and thin cylinderical embrace abundant fat granules. The figures demonstrating the gradual cellular transformation between Zona glomerulosa and Zona fasciculata were obtained, but the independent transitional zone was not visible. It was different from the pictures in hamster and guinea pig that the fasciculata cells contain a lot of fat granules.

The appearance of Zona glomerulosa of cats is quite discriminative from that in $\operatorname{dog}$ and rather akin to various rodentia above described: The cords make the upward extension to end beneath the capsule as the blind tip which contains only a few number of fat granules contrary to the case of dog. Also evidence is present that the gradual conversion of cortical cells themselves is undertaken between two zones.

In the capsule of ox extraordinarily thickened terminate the cords ascending from the inner part of cortex. The tip is shadowed with the numerous stainable granules instead of fat droplets. In a certain sections, it appears as if it were an islet. However, the apparent proof is shown that cords appearing in the capsule are synonymous with the prolongations of Zona fasciculata. Also zona fasciculata of ox embraces the majority of stainable granules, but none of fat droplets.

Adrenal cortex of pigs is concerned, it almost agrees with that of ox in respects of not only the appearance of Zona glomerulosa but also distribution of fat droplets witin the cortical cells.

Zona glomerulosa of horses is similar to that of dogs providing the pattern of Zona arcuata. The cellular components narrow and elongated also packed the stainable granules, but are poor in fat droplets in contrast with the bulky package of the latter in dog. The various intermediary steps showing the inclination of selftransformation were shown between the Zona glomerulosa and Zona fasciculata. Although the fasciculata cells, small in size, were charged with stainable granules exclusive of fat droplets, we could even distinguish Zona spongiosa roaded with the coarse fat droplets.

Zona glomerulosa of goats is coincident with that of ox and pig in respect of its structure and arrangement. The transitional zone is not also capable to be found in this animal. Special remark is laid down upon the absence of fat granules within the cell bodies. This is also synchronized with the cortical cells of the hamster.

Upon above comparative histology of various mammals, we came to a conclusion that the exact zonation of adrenal cortex not afford to be established on the reason 
that Zona glomerulosa is composed of manifold prolongations of cords in Zona fasciculata, and further gained an assumption that the fat droplets may be depo-form vehicles of hormone. The functional significance of protein bound fat particles were discussed in reference to steroid hormone biosynthesis.

\section{文献.}

Bachmann, R.: Z. mikr.-anat. Forsch. 45 (1939). S. 157. - Erg. Anat. 33 (1941). S. 31. - Bennett, H. S.: Anat. Rec. 73, Suppl. 2 (1939 a). P. 6. - Proc. Soc. exp. Biol. Med: 42 (1939b). P. 786. - Amer. Assoc. Rec. 76. Suppl. 2 (1940). P. 5. - Amer. J. Anat. 69 (1941). P. 333. - Cater, D. B. and J. D. Lever: J. Anat. 88 (1954). P. 437. - Diene, H. W., J. H. Shaw and R. O. Greep: Endocrinol. 43 (1948). P. 133. - Elias, H. and J. E. Pauly : Endocrinol. 58 (1956). P. 714 . - Gaunt, R. C. H., Tatbill, N. Antochak and J. H. Leathem : Endocrinol. 52 (1953). P. 407. - Giroud, C. J. P., J. Stackenko and E. H. Venuing : Proc. Soc. exper. Biol. Med. 92 (1956). P. 154. - Gottschau, M.: Arch. Anat. u. Physiol. 1883. S. 412. - Greep, R. Q. and I. C. Jones : Recent progress in hormone research. Vol. 5. 1950. P. 197. - Jones, I. C.: Endocrinol. 45 (1949). P. 514 . - Jones, I. C. and C. C. Roby : J. Endocrinol. 10 (1954 a). P. 245. - Jones, I. C. and M. H. Spalding : J. Endocrinol. $10(1954$ b). P. 251. - Jones, I. C. and A. Wright : J. Endocrinol. 10 (1954 c). P. 262. - J. Endocrinol. 10 (1954 d). P. 266. - Knigge, K. M.: Endocrinol. 55 (1954). P. 731 . - Lever, J. D.: Endocrinol. 58 (1956). P. 163 . Muller, A. F., A. M. Riondel and E. L. Manning: Lancet. 271. (1956). P. 1021. - Orti, E., E.P. Ralli, B. Laken and E. M. Dumm : Amer. J. Physiol. 191 (1957). P. 323. - Pauly, J. E. : Endocrinol. 60 (1957). P. 247. - Rotter, W.: Z. Zellforsch. 34 (1949). S. 547. 一 Rauschkolb, E. W., L. Gordon, G. L. Farrel and S. Koletsky : Amer. J. Physiol 184 (1956). P. 55. Roaf, R.: J. Anat. 70 (1935). P. 126. - Salmon, U., J. Nussmann and R. L. Zwermer: Anat. Rec. 80 (1941). P. 421 . - Selye, H. and H. Stone: On the experimental morphology of the adrenal cortex. 1950. - Tadokoro, S.: Gunma J. Med. Sci. 3 (1954). P. 121. 横須賀 篤: ホルモンと臨床. 6 (1958). P. 251. - Yoshimura, F.: Endocrinol. Jap. 1 (1954). P. 177. 一吉村不二夫: 内分泌. 2 (1955). P. 191.一木ルモンと臨床. 7 (1959). P. 95. 一Wexler, B. C., A. P. Rinf ret, A. C. Griffin and H. L. Richardson: Endocrinol. 56 (1955). P. 120 . 